\title{
INTERNATIONAL FREEDOM OF INFORMATION
}

\author{
Erwin D. Canham*
}

At the first session of the United Nations General Assembly, the importance to the preservation of peace of the freer interchange of information was clearly recognized. Indeed, the significance of the people's sources of news was well understood by many long before that. On several occasions, the League of Nations sought to take measures to lower barriers which hampered the interchange of information. Newspapermen themselves, particularly in the western democracies, have long maintained pressure on governments to help in lowering these barriers. As early as the I89o's they began concerted international efforts to secure a more ample passage of news across boundaries.

When, early in World War II, it became clear to many that the basic conflict in the world was in reality a war of ideas, there began an intensive effort to see that after the war was over, the removal of barriers to the interchange of news should be an essential part of the peace aims. Early in I945, before the United Nations Charter was drafted in San Francisco, the American Society of Newspaper Editors sent a committee of three around the world to investigate conditions of newsgathering and transmission and to recommend measures that could be taken.

Mr. Kent Cooper, general manager of the Associated Press, and Mr. Hugh Baillie, president of the United Press, had for many years made many practical contributions to the lowering of barriers. In the years between the wars, both organizations had contributed materially to breaking down the monopolies by which news had been cartellized in the hands of governmental news agencies. They, and alert newspapermen in many countries, joined in one way or another in the campaign to facilitate a freer flow of news. As World War II ended, there were high hopes that a lowering of news barriers might contribute measurably to popular understanding everywhere of the conditions requisite for a stable and peaceful world.

Despite all this awareness, very little actual progress has been made since the end of World War II to improve the flow of objective information to people. Indeed, there are probably more obstacles to news-gathering and transmission in mid-r949 than there were at the end of 1945 , for such barriers rather accurately reflect the international climate and the state of tension between nations. The international effortlargely centered on the United Nations-to follow the victory in I945 over nazism and fascism with a new era of free information has had certain external successes,

* A.B., D.Litt. Bates College; A.B., M.A. Oxford University; D.Hum. Boston University, Kenyon College, Yale University. Editor, The Christian Science Monitor. President, 1948-49, the American Society of Newspaper Editors; U. S. delegate to United Nations Conference on Freedom of Information, Geneva, 1948; U. S. alternate delegate to United Nations General Assembly, 1949; member, U. S. Commission on Information. 
but in real fact conditions have not improved. The people in many parts of the world are still not accurately or objectively informed about events, and their ignorance or delusions are a prime cause of international mistrust and instability.

Let us first examine the kind of information the people of the world are now actually getting, and then let us see what the United Nations-or anybody else-can do about it.

\section{INFORMation IN THE United States}

First, the American people. With all the deficiencies of the United States press and radio-and no candid American journalist would seek to whitewash themthe fact remains that the American people are the best-informed great people in the world, and they are better informed than they have ever been before. These are plain historical facts.

They should, of course, be much better. informed than they are. But with full recognition of all shortcomings, it is nevertheless true that every twenty-four hours an enormous flow of information about the world pours into the United States, most of it is distributed to newspaper offices and radio stations, and a substantial portion is disseminated to the people. There are some newspapers and some radio stations, of course, which truncate the flow of national and international news, and give prominence largely to the sensational and bizarre.

However, there are great regional newspapers in most parts of the United States which print a very substantial file of national and world news each day. And certain metropolitan newspapers which specialize in careful and comprehensive news have circulation in all parts of the country. Nowhere in the United States is it impossible for an individual to have ready daily access to a reasonably adequate account of world happenings.

Of course, it is important for this news to reach the great masses of people, as well as the specialists or the conscientious few who go out of their way to be well informed. Probably, too, some newspapers tend to underestimate the serious interests of many of their readers. But, conversely, newspapers soon go out of business if they do not retain the vivid interest of their readers, and so the editor must make his difficult daily compromise between the important and the interesting.

At the other end of the news-scale, there are some American correspondents abroad who are not fully equipped to judge and report the enormously complicated events of the vast areas where they work. Some of them, too, are required to furnish piquant rather than significant copy. But these few are considerably outnumbered by experienced, shrewd correspondents who are fearless, acute judges of men and events, and who contribute to the steady flow of important news pouring into the United States.

There are, however, large areas of the world into which such correspondents cannot now penetrate, or from which their copy is rigorously and politically censored. 
In the Soviet Union, the few correspondents permitted to remain there are rarely allowed to leave Moscow, they are not supposed to seek news from anybody except the official spokesmen, and so their opportunities to find out what is going on are gravely limited. In the satellite states of eastern Europe, conditions vary widely. In some, such as Rumania, news-gathering is extremely difficult. In others, such as Poland, few limitations are applied. In China, both nationalist and communist authorities have censored severely in recent times. Censorship is periodically applied in various Latin-American countries. There are thus immense dark areas in the world from which the flow of objective reporting is today impossible.

This is not the place for a detailed examination of the internal shortcomings of the American press. Against these limitations-which have come in for a good deal of somewhat academic criticism lately-must be set the dynamic force which has produced the American news-gathering system. In the nineteenth century virtually all American newspapers were severely biased partisan organs, and the press associations had only begun to girdle the globe. Today, news reporting in American newspapers has become relatively objective.

Anyone whose concept of the limitations of American newspapers makes him doubt this statement, is invited to examine the files of American dailies at any time in the nineteenth century, or for that matter at any previous time in the twentieth century. The news service given readers has grown steadily better.

Meantime, the American press associations have freed themselves from inhibiting relations with other national press associations-most of them formerly governmentally controlled-and do an independent job everywhere in the world that they are permitted to operate. Moreover, the three American press associations-the Associated Press, the United Press, and the International News Service-sell news to news agencies and newspapers in nearly every foreign country. They are today the chief purveyors of news in the whole world. Their relative objectivity and independence make this function immensely important. But the preeminence the American press associations enjoy has also brought problems, which will be examined in due course.

In addition, a few American newspapers-but very few-maintain their own staff of foreign correspondents. In prosperous times, the news weeklies also keep extensive staffs of correspondents abroad, and so do the radio networks. But the basic core of news reaching Americans from overseas comes through the three press associations. On the whole, as I have said, they produce a broad and balanced file of news. But, since it is an essentially commercial operation, and must be based upon popular interest, it will often have to sacrifice so-called importance to reader interest.

After all, information is of no importance or value until it has entered into the consciousness and thinking of the reader. Somehow, it must be made interesting enough to penetrate. The academic critic must not be too supercilious about reader interest, and the newspaperman must remember basic significance. Between these 
two fixed points, the American citizen remains actually better informed than the citizens of most of the rest of the world, although there is still a long way to go before Americans know all they need to know to carry their burdens of world leadership.

\section{II}

\section{Information ABRoAd}

The information which reaches the people of western Europe, and of the British commonwealth nations, comes next in the scale of adequacy. Indeed, the splendid newspapers of smaller countries-Switzerland, Scandinavia, the Netherlands, the commonwealth-may well convey a higher degree of information than does the American press generally. Comparisons are perhaps invidious.

Canadian newspapers are very much like their United States counterparts. In Britain, for nearly a decade, and in most continental countries, severe newsprint shortages have decimated the flow of news. Editors have managed miracles of condensation. But all the same, a great deal of essential information and discussion has inevitably failed to reach the people. Basic facts are known, but plenty of contributory factors have been passed over.

Few European countries have ever given adequate news attention to the United States. This is nearly as true of Great Britain as it is of the Latin countries. Scandinavia has done very well. The American press associations, which disseminate part of the American news reaching these areas, must bear a share of the responsibility, for they have too often merely given "what the readers want"-that imperative but not exclusive standard-and it has often included an inordinate amount of sensation and trivia.

The B.B.C. has done an excellent job of conveying dispassionate, uncolored news to the British people, especially of the United States. The British and commonwealth nations receive much of their news through Reuters, which has been organized in recent years into a newspaper-owned and managed cooperative closely modelled after the Associated Press. Its direct connection with the British government has been dissolved, and it is a dynamic and effective news-gathering network, along with Agence France-Presse. It is the only world-wide agency to compare with the American services-with the exception of the Soviet agency TASS, which is quite another story.

In France, strenuous efforts have been made to prevent the pre-war corruption of the press from returning. Numerous newspapers which were published clandestinely during the Nazi occupation have tried to convert themselves into a free and democratic press. Some of them have sought to remain independent from party affliation. They are fighting an uphill battle.

There are so many French daily newspapers, that economic security and selfsustaining independence are difficult for any of them. Encountering steady deficits, they unavoidably seek financial support from some external source, and either politi- 
cal parties or industrial influences are apt to be the available sustenance. Thus begins the downfall of a truly independent press, for partisan organs almost invariably present a highly colored account and interpretation of the news. It cannot be said that the French people are adequately informed. In Italy, and the other Mediterranean countries, the situation is much the same.

In Germany and Japan, the occupation authorities have labored to encourage and guide the emergence of an independent press. Some progress has been made. But behind the scenes lurk old, military or nationalistically minded elements, which are certain to enter the newspaper field with large financial support the moment occupation controls are lifted. The new, independent press will have to fight for its life.

In Latin America, the press generally reflects the instability and political crosscurrents of the various countries. Two of the greatest newspapers in the world formerly existed in Buenos Aires. They live on in name only, sapped by the Peron regime. Despite their former strength, they proved unable to stem the tides of dictatorship. Their current coverage of the world is largely composed of what they obtain from the American agencies, modified by the political pressures of the government. Here and there in Latin America, a virile and courageous newspaper exists. Numerous Latin-American newspapers are economically prosperous, which helps them to resist political pressures. In vigor and independence, the LatinAmerican press is somewhere between the worst of western Europe and the best.

All the news which reaches the Russian people through their own press-and little gets to them otherwise-must rigorously toe the party line. News from abroad, especially from the United States, is utterly slanted and many important facts are suppressed. The press is a vital organ of government, and it is used tirelessly to support the communist regime. There is a deeper-awareness of the central importance of information in the totalitarian countries than among the democracies. The despots have long since learned that an early step toward despotism must be the suppression of an independent press. In the other eastern European countries, as in communist China, a free press has been ruthlessly destroyed. Therefore, except as the people listen to foreign radio programs, or receive clandestine information, they are far from accurately informed of world events. However, in censorship countries, the grapevine-old as history-takes on inordinate importance. Much news passes along this traditional channel, and sometimes the people know more facts than their rulers believe they do.

From this brief and general survey of information around the world, it will be seen that only a minority of the peoples receive anything remotely resembling an accurate and adequate account of what is going on. The major deterrent, it is clear, is authoritarianism on the one hand-the intervention of government-and on the other hand various defects in the performance of the press itself. These are long-range problems, and they would be affected only indirectly by the campaigns for freedom of information which have been waged through the United Nations. 
Of course, despotisms of various degrees will finally end when the people really know what is happening to them-when they learn the facts of international and sense, will ultimately bring tyranny down. And so the efforts to lower barriers will national life-and thus throw off their chains. Freer information, in the broadest ultimately produce conditions that will bring about a truly free press everywhere. However, that is a very long range view. For the moment, the freedom of information campaign inside the U.N. can only serve to reduce some of the more palpable barriers to the movements of correspondents and news. It can slowly educate governments and peoples to the real significance and essence of an independent press. It can help to arouse a more vigorous responsibility within the press itself. So, having seen what needs to be done, let us turn to the U. N. campaign itself.

III

\section{The Geneva Conference}

At the U. N.'s I946 General Assembly, a resolution was adopted-introduced by Gen. Carlos P. Romulo of the Philippines-calling for an international conference on Freedom of Information. The resolution described freedom of information as "a fundamental human right and ... the touchstone of all the freedoms to which the United Nations is consecrated." To the proposed Conference was assigned the task of formulating views "concerning the rights, obligations and practices which should be included in the concept of freedom of information." The General Assembly further defined freedom of information as implying the "right to gather, transmit and publish news anywhere and everywhere without fetters," recognizing it as "an essential factor in any serious effort to promote the peace and progress of the world."

Such a resolution could be adopted only because the same language means twoor more--different things to governments holding differing political and economic philosophies. These divergencies soon came to the surface as the U. N. proceeded to organize for the Conference on Freedom of Information. A preparatory subcommission of individual experts was set up under the Human Rights Commission, and in its midst as well as in the General Assembly, bitter debates soon began between the delegates of the Soviet Union, of the western democracies, and of various other countries whose views, while not communist or totalitarian, leaned heavily toward some forms of governmental control of the press and of news.

This sub-commission had the task of preparing for the Geneva Conference. It worked its way through a great deal of preliminary ground and the broad positions of various countries were fairly well established. Without the sub-commission, work at the Geneva Conference would have been much more protracted. As well as preparing for the Conference the sub-commission discussed various general principles without, naturally, reaching concrete decisions. The Geneva Conference itself recommended the re-establishment of the sub-commission to carry out many of 
the Conference's recommendations. The sub-commission was newly established in May, I949 and has held one three weeks' session. Its terms of reference are to report to the membership of the United Nations-and hence to the public of the worldexisting information practices, and to point out ways of improving them. It intends to carry out studies of the adequacy of the news at present available to the peoples of the world, censorship restrictions on movements of press personnel and information within countries and across borders, and other obstacles to the free flow of news.

At the re-constituted committee's first meeting in 1949 it was again clear that the communist members would seek to use it as a means of discrediting the information systems of the free world and convincing people that iron-handed controls by government were necessary. The Russian and Yugoslav members unsuccessfully sought to launch the sub-commission on an immediate study of the means of "spreading true information to counteract Nazi, Fascist, and other propaganda of aggression or of racial, national, and religious discrimination." The great majority of the sub-commission spurned this effort to lay the groundwork for controls and has set out upon the task of studying present and future information problems.

Andrei Vishinsky's most violent attacks upon the United States often centered on the American press, which he accused of being a venal capitalist tool of fascism. Soon a communist line of criticism of the American and British press was developed and hardened, and continued to be invoked whenever the subject came up, to the moment this article is written. Doubtless it will continue to be used until world conditions change materially. This case is basically a defense of the controlled press of the communist states, which is claimed to be the only "anti-fascist" press in the world, coupled with bitter all-out attacks on the western press as war-mongers.

The various criticisms of American and British newspapers which have been evolved mostly out of the healthy self-analysis which is the strength of our free system, have been invoked by the communist spokesmen. The report of the Hutchins Commission, the books of Morris Ernst and the Nieman Foundationindeed, every work which ventures to point out some of the unfinished business of the American press-is used as grist to the mill. The American and British press are declared to be monopolistic-as if the existence of some $x, 700$ independent dailies in the United States and three vigorously competing world-wide press associations was a monopoly that compares to the iron-clad control by government of the Soviet press.

For a time, these communist arguments made a certain impression both in the West and among the in-between countries, for they coincided with the genuine self-criticism of the press prevalent in free societies, and they fitted the resentments of the have-not countries against the great, world-girdling press associations and newspapers. The arguments were unfolded in the General Assembly, and in the preparatory sub-commission. Though the United States and British delegates tried 
to make clear that the so-called "war-mongering" resolution presented by communist delegates was merely a blind in defense of a controlled press, it was impossible to defeat the resolution at the Assembly of 1947. The tide seemed to be running against the western concept of an independent press. Therefore, the American delegation went to the conference on Freedom of Information, held in Geneva in MarchApril 1948 , with meagre expectations.

We found at that Conference, however, that the brutality with which the communists had just taken over Czechoslovakia, plus the beginning impact of the Marshall Plan, were beginning to blow away some of the delusions of the in-between states. It was not inordinately difficult to work out three conventions and fortythree resolutions-by large majorities-which were with one single exception adequately reflective of democratic experience in the field of free information. At Geneva, there were many professional newspapermen among the delegates. They understood from practical experience the importance of protecting the press from governmental controls, however artfully disguised. They brought great influence to bear on their own governmental delegates, who otherwise might not have been so clear.

So the outcome of the Geneva Conference was excellent. The first convention, on the Gathering and International Transmission of News, was a simple and straightforward undertaking, originally drafted by the United States. It limited itself to helping the job of the foreign correspondent: a tangible and practical objective.

The convention called upon contracting states to encourage the freest possible movement of foreign correspondents in entering or leaving their countries, to give the widest possible access to news sources, to permit egress of copy without censorship, editing, or delay except in matters "relating directly to the maintenance of national military security" and then under specific conditions to protect correspondents against unlawful or arbitrary expulsion, and otherwise in general to assist the daily operations of correspondents and information agencies.

A second convention, on an International Right of Correction, was introduced by the French. Originally, the French would have preferred to make this convention compulsory, requiring any newspaper anywhere to print a correction upon demand of some government which believed itself misrepresented. Also, the French wished to propose an international identity card without which foreign correspondents would not have functioned freely, and a Court of Honor which would have disciplined their transgressions. It was pointed out to the French delegation that the identity card might come to be nothing less than a license to be a journalist. Establishment of the licensing power over the free expression or transmission of ideas is the very antithesis of freedom of information. And it was objected that the Court of Honor might be seriously abused.

Recognizing that the English-speaking and Scandinavian delegations felt very strongly on these points-as did a few Latin Americans and some others, like the 
Philippines-the French gracefully withdrew their more extreme concepts, but stuck to the convention on Right of Correction. As worked out, this convention was not compulsory, and held promise of affording some redress to governments which might havie been misrepresented. It was adopted with little opposition.

Somewhat surprisingly, the British delegation introduced a third convention, on Freedom of Information, which laid down general principles in so broad and sweeping a manner as to give the United States, some commonwealth nations, and the Scandinavian and Netherlands delegations, very considerable disquiet.

To many, the British convention seemed contrary to usual Anglo-Saxon pragmatism. The first article, for example, called upon a contracting state to "secure to all its own nationals and to the nationals of every other Contracting State lawfully within its territory freedom to impart and receive information and opinions, orally, by written or printed matter, in the form of art, or by legally operated visual or auditory devices without governmental interference."

It was not with the purpose of this clause, or of the convention as a whole, that the United States felt disturbed. It was the precise legal effect. I leave to the legal readers of this quarterly an interpretation of the effect of the foregoing clause upon many American statutes-national, state, or local. Remembering that a treaty becomes law of the land, and that conflict with any other law can only be determined in the courts, it seemed impossible to the American delegation to discover in advance what laws might be nullified by the provision. For example, would the F.C.C. statute-by which the federal government consciously discriminates in the allocation of radio frequencies-stand up under such a treaty obligation?

Or what about the F.C.C. in view of the next clause in the proposed treaty: "No contracting state shall regulate or control the use or availability of any of the means of communication referred to in the preceding paragraph, in any manner discriminating against any of its own nationals or of the nationals of any other Contracting State on political or personal grounds or on the basis of race, sex, language or religion." Here, emphatically, it seemed as if the F.C.C. statute and some others might well be nullified.

That was not all. In Article 2, the convention declared that the freedoms referred to above "carry with them duties and responsibilities and may therefore be subject to necessary penalties, liabilities and restrictions clearly defined by law, but only with regard to...." Whereupon the convention listed ten areas in which limitations might be imposed.

This limitation clause did not aid the United States in preventing the nullification of useful and innocent statutes like the F.C.C. But it did open wide areas of possible abuse. Some of the limitation clauses were familiar and necessary, such as "expressions which incite persons to commit criminal acts." Paragraph (j) added to the specifications under which freedoms might be limited the following ground: "the systematic diffusion of deliberately false or distorted reports which undermine 
friendly relations between peoples or States." If freedom of information may be limited on that ground, then the door is wide open to censorship of any sort.

The American delegation felt that to spell out specific grounds on which freedom might be limited-as in these ten areas-was to invite the formulation of controls. Such a list, moreover, might not include the very basis on which some government, for the best and most freedom-loving of reasons, might have to impose certain controls-such as the F.C.C., or that part of the Securities Exchange Act which "censors" the contents of stock prospectuses, or municipal ordinances which prohibit sky-writing in the vicinity of air fields. The American delegation therefore proposed a general limitation clause which would meet any legitimate situation, but would not run into the hazards of inviting controls on the basis of "false or distorted reports." That phrase-which comes straight from Soviet propaganda against the "war-mongering western press"-embodies the starkest concept of controlled and penalized newspapers and a totalitarian system.

But the American delegation was quite unable to persuade a majority of others to support a general limitations clause, or even to see the particular legal difficulties which Article I would create in the United States. The convention, bristling with these unsolved problems, was adopted by the Geneva Conference. To some of the troubles, there were legal remedies. For example, a so-called "non-self-executing clause" was subsequently drafted and proposed at the Third Assembly. It met with some questions and more incomprehension, but has not been acted on finally. If included in the treaty, it would avoid the conflicts with American legislation. It would not have removed the possibilities of abuse of the various specific limitations on freedom of information in Article 2.

Despite the shortcomings of the British convention, the general outcome of the Geneva Conference was encouraging to those who had been foremost in the crusade for freer information channels. It had revealed a notable waning in Soviet capacity to bemuse the middle nations with fine but ambiguous words. The iron core of communist press policy was now apparent. The aggressive line taken by the American delegation against totalitarian controls had been successful.

\section{IV}

\section{The Third Assembly}

But the Geneva Conference was only an opening skirmish. A few months later, also at Geneva, the Human Rights Commission of the Economic and Social Council met to go over the three conventions and the forty-three resolutions adopted by the Conference before they were submitted to the Third Assembly, due to meet in Paris in September, I948. At the Human Rights Commission meeting, the American delegation ran into rude surprises. First, the Soviet delegation staged a virtual filibuster for three weeks, attacking the American convention, and preventing any work on any of the others. In one respect, the American convention was almost 
fatally wounded. The crucial clause on censorship, which had forbidden peace-time censorship except for reasons of national military security, was rendered a potent instrument of repression by simply deleting the word "military." The phrase "national security" would of course permit a government to impose censorship any time it chose. This was done by a vote of eight to seven, with several delegations which should have known better-notably France and Australia-voting for the dangerous language.

The three conventions were expected to be discussed at the Paris meeting of the Third Assembly in September-December, 1948, but the pressure of other work kept them from consideration. They were deferred until the meeting of the second session of the Third Assembly, at New York in April-May, 1949.

Here, almost as soon as the Assembly's Third Committee on Social and Humanitarian Affairs began its work, it was seen that the climate had changed again. Many countries which, at Geneva, had been guided by expert newspaper specialists on their delegations, were now back in the sphere of professional diplomacy. In the year that had elapsed since the Geneva Conference, the Foreign Offices, the Home Offices, the Colonial Offices-and many others-had been studying the texts.

The natural desire of government to cling to power had greatly moderated the sympathy with freedom which had prevailed at Geneva. Little changes of language, "safeguarding" clauses, and amendments of ingenious import had been concocted. Had one tenth of the amendments proposed at Lake Success been inserted into the American convention-which henceforth was called the first convention-it would have been converted into a dangerous mechanism of press control, instead of a charter of liberties.

Wide chasms of misunderstanding opened between the small group of nations which have had experience of genuine press freedom, and those which lean toward controls. Two big groups of nations-the Latin Americans and the Arabs-had a very serious "have-not" attitude toward the American press associations and the United States press in general. The Arabs, in particular, were imbued with a deep bitterness resulting from the Palestine dispute, in which they felt the American press had not fairly stated their case.

The first challenge which the first convention met at the General Assembly was as unexpected as it was serious. The Chinese delegation, supported by numerous others, proposed to change the definition of correspondent so as to exclude nationals who work in their own country in the employ of a foreign newspaper or news agency. This would have meant that a substantial number of the individuals now gathering and disseminating news for international consumption throughout the world would have been deprived of the advantages and guarantees of the treaty. Its value would have been cut by $5^{\circ}$ per cent.

The reasoning behind this damaging proposal was complex and revealing. For the Chinese, the concept of one of their own countrymen enjoying a special status 
in his own country under a treaty-almost extraterritoriality-was abhorrent. For many nations, the idea of giving their own nationals some kind of special protection -through the intervention of a foreign agency or foreign government-was undesirable. There was no intention, of course, of coming between a national and his own government by treaty and by foreign intervention. All that the convention sought to protect was the function of international news-gathering. The national as a foreign correspondent, not as a private individual, was to have specified and limited privileges.

Without such protection, the convention would have been virtually valueless in many countries. In the Netherlands, for example, nearly all the journalists providing news for foreign consumption are themselves Netherlanders. To exempt them from the treaty would have been a total surrender. Only by the scantiest of majorities was the original definition of correspondent-in effect one who sends news abroad-retained in the treaty. In the end, it became necessary to include a more complicated explanation in the convention, under which it was made clear that the treaty did not establish any power to come between a government and one of its own citizens.

This was only the beginning of the technical difficulties. The second Geneva convention-on an international right of correction-was incorporated with the first, or American, convention by agreement of the French delegation, which sponsored it, and other primarily interested delegations.

This right of correction, as drafted at Geneva and as ultimately agreed upon at Lake Success, gives a government the right to submit to another government its correction of an allegedly incorrect dispatch originating in its territories and published in the territories of the second country. The second government is then required to release the correction to the press through its customary channels. If it fails to do so, the release is made through the channels of the United Nations.

No compulsion is involved at any point to require a newspaper or news agency to publish or distribute such a correction. Were compulsion involved, the device could be made the means of forcing propaganda into the columns of newspapers, and would be very dangerous.

There was some sentiment in favor of compulsory correction among the delegations of several smaller countries. Their interest was apparent. It would have offered them a potent opportunity to force their viewpoints into the vast American press. A compulsory right of correction would have been a one-way street, running against the United States.

Suppose such a treaty obligation had existed prior to World War. II, and Germany had been a party to the treaty. It would have been the professional duty of American correspondents in Berlin to send factual dispatches revealing the rearmament plans of the Nazi government or its ruthless persecutions. Yet that government would have been able to contend that these dispatches were "false or distorted," and 
by unilateral fiat might have forced its replies into the columns of the American press wherever the original dispatches had been printed.

Using such arguments, it was possible to keep a compulsory right of correction out of the treaty. The correction process, as adopted, is in accord with the best practices of responsible journalism. Newspapers and news agencies are customarily entirely willing to publish corrections when they have been proved genuine. But it took long and ardent discussions and negotiations at Lake Success to keep compulsion out of the treaty.

Another crucial point concerned the basis for censorship. In the original Geneva draft, as we have seen, peacetime censorship was permitted only on grounds of national military security. At the Human Rights Commission meeting in Geneva, by deleting the word "military," the door was open for censorship at the whim of any government. At Lake Success it was even proposed to add the words "national prestige and dignity" to the grounds on which censorship might be imposed in peacetime. These words would have compounded the abusive possibilities. Only after extremely careful negotations were they kept out of this context.

It was also proposed to lay down-without defining the means of enforcement -a so-called duty of newspapers and information agencies "to report facts without discrimination and in their proper context and to promote respect for human rights and fundamental freedoms ..." etc. It was proposed, in short, to add to the operating clauses of the treaty, the kind of language which had originated in the Russians' war-mongering resolutions. As operational obligations, these clauses would have given governments the grounds for imposing various restrictions and penalties upon correspondents or agencies, on the mere assertion of non-fulfillment or violation. Such a result would have ruined the treaty. After long negotiations, this language was all placed in preambulary context, where it refers to professional ethics rather than to legal obligations.

None of these dangerous proposals were advanced by the Soviet government or its satellites. The amendments these delegations advanced were the same old proposals to give governments power to require "truthful news" and were transparent devices for totalitarian control. They were readily defeated.

The dangerous proposals came from nations like Mexico, nationalist China, or India with which it should have been possible-and usually was-for the United States and its like-minded associates to agree; and after much mutual explanation, it was possible for agreed texts to be reached. But these texts were attainable only after a vigorous press campaign in the United States, and intensive discussion at Lake Success. The necessity for such discussions revealed the existence of a wide breach between the concept of freedom of information in eight or ten countries, like the United States, Britain, Scandinavia, the Netherlands, and the commonwealth, on the one hand, and that in much of the rest of the world on the other. Many governments, which maintain the most impeccable principles of freedom in their consti- 
tutions and their oratory, actually impose various forms of control over the press, and would have written these proposed controls into the treaties. But in the end, at Lake Success, all these hazards were excluded from the combined AmericanFrench convention.

When work was begun on the third, or British convention, the difficulties pyramided. The list of specific exemptions, bad enough as it came from Geneva, was made considerably worse. It was voted, for example, to add to the explicit bases on which guarantees of freedom could be suspended, the following grounds:

For the prevention of the diffusion of reports for racial, national or religious discrimination.

For preventing the diffusion of false or distorted reports which undermine friendly relations between peoples or States.

It will readily be seen that such vague and general stipulations would permit the complete nullification of any guarantees of freedom. The British denounced their own convention, with these additions, and supported a proposal to defer work on it until the Fourth Assembly should meet in September. By that time, it was hoped that diplomatic interchanges would have removed some difficulties.

To some delegations, the British convention (now called the second convention) consists of obligations of the press, while the first convention consists of privileges for the press. 'This is not the viewpoint of the British, American, or other delegations. But the great majority of have-not nations (they "have not" large, powerful press associations or the concept of the free press which has grown up in Englishspeaking and western-European countries) have little enthusiasm for the first convention. They insist that the two conventions must be coupled together. Partly to meet this view, it was agreed not to open the first convention to signature and ratification (although it is completed) until the second convention has been disposed of. That will be the task of the Fourth Assembly.

\section{$\mathrm{V}$ \\ The Future}

There will be many sticky problems ahead, before the second convention is either amended so that American, British and other governments can accept it, or is placed indefinitely on the shelf. If it is adopted, against British-American protests, they and a considerable number of nations can never sign it. Possibly their reluctance will doom the first convention, too, as a reprisal by the other nations which do not like it.

There are, therefore, the following alternative possibilities as the outcome of these years of United Nations' effort:

(r) The first convention on Gathering and International Transmission of News and the International Right of Correction may be signed and ratified. It should then prove to be a moderate and practical aid to news-gathering and dissemination 
in many parts of the world. Since the Soviet Union and its satellites have repeatedly proclaimed their deep repugnance for the treaty, they are most unlikely to sign it. Therefore the treaty would do no immediate good in the areas where restrictions are greatest. It would not directly help to lift the iron curtain. But it would be of value, all the same. It would be a beginning: an initial charter of liberties for the indispensable act of gathering and transmitting news, with the addition of the right of correction.

(2) The second convention on Freedom of Information may be signed and ratified. Even if improved, it is unlikely that the United States would find it worth while to support this document. Its advantages, such as they may be, are to be duplicated in the Covenant on Human Rights. The convention, at best, is a noble declaration of principles. At worst, it could be the basis of restrictive action, serving perhaps to nullify the advantages of the first convention, and even worse, to set up barriers and controls which do not exist.

(3) The United States Senate might choose not to ratify the first convention. In that case, if other nations did so and the treaty came into operation, all its guarantees and advantages could be limited legally to correspondents and information agencies of signatory states. American correspondents and agencies could be the victims of the most severe discriminations in history. This is a serious possibility, which calls for careful study.

(4) Both conventions may fail the necessary signatures or ratifications, for one reason or another. In that case, the primary blame can be placed on today's international climate, which has certainly not turned out to be salubrious for new freedoms in areas where they are now restricted.

Two great facts stand out. One is the familiar truth on the basis of which the entire freedom of information crusade is premised: that it is highly important to the cause of peace and understanding to reduce present barriers. This will remain true whatever happens to the present crusade. But these experiences may raise great questions regarding the possibility of freedom coming through governmental action. It is quite likely that greater progress could now be made through cooperative efforts of the information media themselves.

The second fact is that the United States and its news organs are in the line of fire, which is perhaps the unavoidable fate of a great power. There is much resentment against these agencies on the part of foreign governments-though not necessarily on the part of foreign newspapers or peoples. Our newspapers and information agencies are big, strong, rich, powerful. They are a tempting target. Everyone wants to get his story in the American press, nearly everyone feels he is misrepresented there.

If the United Nations, or any other organism, is to make genuine progress toward reducing information barriers, it will be because the press itself has awakened far more realistically than at present to the essence of the problem. 